Society for the Anthropology of Work • Policing and Labor

\title{
Escaping Policing: Labor, \\ Risk, and Abolition in \\ Johannesburg
}

\section{Paul Clarke}

Published on: Dec 01, 2020

DOI: $10.21428 / 1 \mathrm{~d} 6 \mathrm{be} 30 \mathrm{e} .5 \mathrm{c} 4 \mathrm{~d} 8 \mathrm{fc} 5$

License: Creative Commons Attribution 4.0 International License (CC-BY 4.0). 
On March 15, 2020, South African President Cyril Ramaphosa announced that the entire country would be shut down for twenty-one days. The lockdown in response to the COVID-19 pandemic was one of the world's most stringent, banning the sale of cigarettes and alcohol as well as take-away food. Among the few businesses exempted were the country's more than eight thousand private security firms, which alongside hospitals and supermarkets were deemed essential to South Africa's response to the coronavirus.

For Esaia, ${ }^{1}$ an armed response officer in the city of Johannesburg, the president's order had a paradoxical effect. The streets were empty, and the hijacking and robbery syndicates that make their livelihoods in the city's affluent suburbs were staying at home too. With property crime in steep decline, the pandemic had made his job less dangerous than before. "Some of us are no longer sweating like we used to," he told me over the phone.

These quiet shifts suited Esaia just fine. They promised a month's salary that didn't require him risking his life on patrol. Lockdown would end eventually, he reasoned, and the syndicates would return. But by that time, Esaia hoped that he'd be out of security work altogether. He had bought a second car and had his eye on a third. With a little more cash, he could focus solely on his transportation business.

Esaia's timing was good. News had trickled down that the holding company that owned the security firm was preparing to sell. Having purchased it recently as part of a venture into security and risk solutions, the owners were looking to spin off what the business press termed "segments considered to be noncore to future strategy." Many of those employed in the noncore segments, it was rumored, would be retrenched.

This was no surprise to Esaia. He was already making plans when we saw each other in July 2019. Nor was he unique in this regard. Rather, he was the latest in a series of young armed response officers I've met who have soured on security work. Each had invested years into working their way up. But one by one, they made quiet plans to escape their jobs. There was, they said, no future in security. 
The anthropologist Brad Weiss (2004: 9) has argued that, in those African societies where neoliberalism has most firmly dug in, "the very capacity for self-definition and regeneration, the prospects for shaping and securing something like a future" is increasingly produced via "pervasive speculation." Security is a special domain within this speculative economy in South Africa, where risk is the vehicle of value production for those at the top and bottom-but the risks being taken at the bottom are existential. This condition of "gambling with your life," as officers put it, is not unique to South Africa or even to privatized policing. Rather, I want to suggest that it is the essential condition of policing under capitalism. As long as capital accumulates, it will need some to risk their lives in order to protect and quicken its predation. And as it quickens, capital will seek to lower the price it pays for protection. Far from an exception, the situation of security work in South Africa is a potential endpoint for policing in this late capitalist era. Below, I sketch how this condition has come into focus for some officers, making security an unsustainable form of labor for them. In this light, it is not only policing's impact on society's most vulnerable but also its toxic effect on the police themselves that merits its abolition. I then conclude with a blueprint for an abolitionist anthropology of the police.

Because crime syndicates do not work set hours, security is a commodity that must be delivered all day, every day. Officers work twelve-hour shifts on a rolling schedule: three day shifts (6am-6pm), three night shifts (6pm-6am), two days off, and repeat. This schedule is designed on a principle of fairness; nobody gets stuck working nights and everyone shares the busier day shifts. But the constantly shifting hours jangle the nerves. The work is defined by long periods of nothing, so naturally some officers steal time to sleep. Since vigilance is essential to the commodity that is being sold, sleeping on duty is a fireable offense and firms mobilize all kinds of surveillance to maintain discipline. Supervisors make spot checks, guardhouses are equipped with internal cameras, and guards are issued trackers that alert supervisors when regular patrols are not made.

Turnover is high, especially among guards who are unarmed and as a result make the minimum wage of R4337 (US\$250) per month. But Esaia's firm has little trouble filling empty positions. Since the end of apartheid, once-reliable jobs in mining and 
manufacturing have dried up. Young black men, especially those from nearby townships and from the rural areas of Southern Africa that served as apartheid's old labor reserve, have flocked to the security sector. There are some 1.7 million licensed security officers in South Africa today-70 percent of whom are not currently employed in the industry. With nationwide unemployment at 28 percent, the firm never lacks for candidates. Even so, it has been experimenting with automation, especially smart camera technology. Cameras, the firm's directors point out, "do not sleep."

Armed response officers, who are charged with confronting would-be hijackers or burglars, bodyguarding, and sometimes escorting high-value freight, cannot be so easily replaced. Response officers make at least R1000 (US\$60) more than guards on account of their training and the greater risks they incur. Used to working back-toback shifts, they have proven their ability to stay sharp around the clock. Here, the stakes of staying alert are very high. The city's syndicates are usually well-armed, supplied through illicit connections inside the police and security sector. But weapons, especially response officers' long guns, are still highly sought after. Syndicates are opportunistic. If they see a response vehicle, they will sometimes, as officers put it, "take a gamble" (isiZulu: zizothatha amachance) on attacking officers for their rifles.

To avoid becoming one of those memorialized on the firm's Wall of Remembrance, officers are trained to drive constantly. The vehicles are tracked to ensure that they stay in perpetual motion. These digital trackers are also essential to keeping the firm's competitive edge. As the writer Jonny Steinberg (2009) notes, it is not uncommon for South African police-out of self-preservation-to take their time responding to crimes in progress. Response officers don't have the same luxury. Speed is the substance of security for the homeowners, businesses, and gated communities that make up the firm's client base; they pay security to be faster than the cops and as fast as the syndicates. The firm's directors scrutinize officers' response times closely to maintain their client base. But speed has unintended effects. In their efforts to hurtle toward crime, officers often crash. Car accidents were, a director estimated, a weekly occurrence.

Those who have decided to escape security know the stress and risks of the job. They have seen how these wear on the body. But even so, the job's potential lethality is not central to their reasons for leaving security. After all, lethality has dividends; there is the salary and the masculine self-possession that comes from mastering the weapons and the road. Rather, it is the realization that the value they gain is neither durable nor equal to what they generate for the firm. For Esaia, who entered security out of a 
desire to support his mother and earn enough to build a house in his hometown, it was the holding company's constant reworking of the business model that led him to understand that there was no stability in security. For another officer, Philip, it was glimpsing the yawning difference between the firm's revenue and the salaries it paid. In the months before he quit, he grew increasingly bitter. When I asked over lunch what he thought of revelations of government corruption, he was blunt: "The best thing you can do in this country is find a place where you can steal. Security, it's stealing. It's all stealing."

There is a tendency when writing about labor to propose immediate solutions to ameliorate working conditions. But I want to suggest that it is worth resisting this temptation when considering what is owed to those who do police work. There are, after all, technical problems with immediate solutions like unionization. South African private security officers have unions, albeit weak ones that can secure wage floors but cannot insulate members from the risks of the job. However, one need only look to the United States to see the pitfalls of insulating the police via strong unions. But beyond these technical issues, there is a more fundamental question: would truly just societies need police work at all? This is the question that abolition asks and that anthropologists ought to take on.

It might seem untenable for a field interested in police worlds to suddenly dedicate itself to imagining a world without police. But as Jeffrey Martin (2018: 143) puts it, the anthropology of the police has built up an archive that recognizes in policing "a kind of moral agency that fabricates provisional fixes to a world shuddering under the weight of its own moral incoherence." An abolitionist anthropology of the police would begin from those instances when that moral agency is exercised to opt out-to sleep or quit on the job. In doing so, it could document the forms of desire and the attendant structures that currently make policing a necessary and sustainable form of labor. It could also uncover how those desires can and do become unmoored from policing and, under certain conditions, attached to forms of labor and relationality that generate more universal flourishing.

The archive that an abolitionist anthropology would assemble need not become an archive of triumphant escapes. Abolitionists are interested in unraveling the structures 
that make prisons and police necessary (see Gilmore 2007), and so stories of failed escapes from police work might ultimately be most useful in uncovering the contours of carceral formations. Nor does this project need to traffic in what Martin (2018: 142) calls "reactionary polemics," which are more interested in affecting radicalism than effecting change. Rather, it puts the question to us as anthropologists of whether we who like our informants make livelihoods from policing would-in a just world-want to live otherwise.

\section{Note}

1. All informants' names are pseudonyms.

\section{Author Bio}

Paul Clarke is a PhD candidate in the Department of African and African American Studies at Harvard University.

\section{Preview Image}

Photo by Chris Henry.

\section{References}

Gilmore, Ruth Wilson. 2007. Golden Gulag: Prisons, Surplus, Crisis, and Opposition in Globalizing California. Berkeley: University of California Press.

Martin, Jeffrey T. 2018. "Police and Policing." Annual Review of Anthropology 47: 13348.

Steinberg, Jonny. 2009. Thin Blue: The Unwritten Rules of South African Policing. Johannesburg: Jonathan Ball Publishing.

Weiss, Brad. 2004. "Introduction: Contentious Futures, Past and Present." In Producing African Futures: Ritual and Reproduction in a Neoliberal Age, edited by Brad Weiss, 1-20. Boston: Brill. 